\section{Efficacy of Binary Pesticide Mixtures Against Western Flower Thrips}

\author{
Raymond A. Cloyd ${ }^{1}$ and Amy L. Raudenbush
}

AdDitional INDEX wORDs. combinations, Frankliniella occidentalis, greenhouse, insecticides, miticides, mortality

SuMMARY. This study was designed to determine the efficacy of binary pesticide mixtures against one of the most important insect pests of greenhouse-grown horticultural crops, western flower thrips (Frankliniella occidentalis). Two separate experiments were conducted under greenhouse conditions to simulate a greenhouse production cycle using yellow transvaal daisy (Gerbera jamesonii) cut flowers, which were artificially infested with a known number of western flower thrips. The pesticides used in the two experiments were spinosad, pymetrozine, abamectin, pyridalyl, fluvalinate, chlorfenapyr, bifenazate, azadirachtin, petroleum oil, tolfenpyrad, fenhexamid, azoxystrobin, and spirotetramat. Pesticide mixtures were evaluated at the recommended labeled rates (Expt. 1) and assessments were made to determine if adding didecyl dimethyl ammonium chloride enhanced the efficacy of the pesticide mixtures (Expt. 2). Results from Expt. 1 indicated that many of the binary pesticide mixtures provided $\geq 80 \%$ mortality of western flower thrips although this was a baseline population without previous exposure to pesticides. In Expt. 2, the addition of didecyl dimethyl ammonium chloride failed to increase the efficacy of most of the designated pesticide mixtures compared with the pesticides applied separately. Furthermore, none of the binary pesticide mixtures were phytotoxic to the transvaal daisy flowers. Although there are issues associated with using pesticide mixtures such as the potential for resistance developing to different pesticides in mixtures, greenhouse producers combine pesticides together to reduce labor costs and expand the spectrum of activity against insect and mite (Tetranychidae) pests. Therefore, the relevance of this information is that greenhouse producers now understand which pesticide mixtures may be used and those that should be avoided when suppressing populations of western flower thrips thus minimizing feeding damage to greenhouse-grown horticultural crops.

$\mathrm{H}$ orticultural crops grown in greenhouses may be infested with several insect and mite pest species simultaneously (Cloyd, 2012). However, pesticides may be selective in regards to the insect and/or mite pests they effectively control, yet producers must deal with an array of insect and mite pests (Cloyd, 2009a). Therefore, greenhouse producers often mix pesticides to reduce costs and expand the spectrum of activity against a variety of insect and mite pests although focusing usually on one primary pest. Western flower thrips are extremely polyphagous, feeding on a wide range of greenhousegrown horticultural crops (Gerin et al., 1994; Lewis, 1997; Tommasini and

Department of Entomology, Kansas State University, 123 Waters Hall, Manhattan, KS 66506-4004

We wish to thank the Association of Specialty Cut Flower Growers (Oberlin, $\mathrm{OH}$ ) for providing the necessary funding that allowed us to conduct this study. We also want to thank Drs. Kun Yan Zhu from the Department of Entomology and Mary Beth Kirkham from the Department of Agronomy at Kansas State University (Manhattan) for reviewing an initial draft of the manuscript.

${ }^{1}$ Corresponding author. E-mail: rcloyd@ksu.edu.
Maini, 1995). Western flower thrips populations are a major concern of greenhouse producers because of both the direct and indirect damage they cause to greenhouse-grown horticultural crops (Mound, 1996; Ullman et al., 1993) as well as their ability to develop resistance to commonly used insecticides (Immaraju et al., 1992; Jensen, 2000; Kirk, 2002; Loughner et al., 2005).

Pesticide mixtures are combinations of two (or more) pesticides in a single solution (Brattsten et al., 1986;
Cloyd, 2011; O’Connor-Marer, 2000; Roush, 1993). Producers apply pesticide mixtures to reduce labor costs as fewer applications are required (Cabello and Canero, 1994; Cloyd, 2009a). A pesticide mixture exposes individuals of a pest population to two or more pesticides simultaneously (Tabashnik, 1989) thus affecting populations of multiple pests (Warnock and Cloyd, 2005). Pesticide mixtures may also be used to broaden activity against all life stages (egg, larva/nymph, or adult) of the pests (Cloyd, 2009a). Pesticide mixtures should be used within an integrated pest management strategy that includes scouting, cultural control, sanitation, physical control, and biological control (Bielza, 2008; Cloyd, 2009b; Hoy, 1998).

Certain fungicides have been demonstrated to increase the efficacy of pyrethroid-based insecticides in binary pesticide mixtures (Thompson and Wilkins, 2003). For example, the fungicide, prochloraz, enhances efficacy of the pyrethroid-based insecticide, alpha-cypermethrin. Furthermore, the fungicides epoxiconazole and propiconazole are oftentimes mixed together with pyrethroid-based insecticides to increase efficacy against both fungi and aphids (Aphididae) on winter wheat [Triticum aestivum (Norgaard and Cedergreen, 2010)]. It has also been reported that mixing the fungicide, triforine, with the insecticide/miticide, abamectin, enhances efficacy resulting in 95\% mortality of twospotted spider mite (Tetranychus urticae) eggs, larvae, and adults (Wang and Taashiu, 1994).

There is minimal quantitative data associated with the effect of mixing fungicides with insecticides although fungicides are routinely mixed with insecticides and miticides (Cloyd,

\begin{tabular}{lllc}
\hline $\begin{array}{l}\text { Units } \\
\text { To convert U.S. to SI, } \\
\text { multiply by }\end{array}$ & U.S unit & SI unit & $\begin{array}{l}\text { To convert SI to U.S., } \\
\text { multiply by }\end{array}$ \\
\hline 3.6967 & dram $(\mathrm{s})$ & $\mathrm{mL}$ & 0.2705 \\
29.5735 & $\mathrm{fl} \mathrm{oz}$ & $\mathrm{mL}$ & 0.0338 \\
0.0781 & $\mathrm{fl} \mathrm{oz} / 100 \mathrm{gal}$ & $\mathrm{mL} \cdot \mathrm{L}^{-1}$ & 12.8000 \\
7.8125 & $\mathrm{fl} \mathrm{oz} / \mathrm{gal}$ & $\mathrm{mL} \cdot \mathrm{L}^{-1}$ & 0.1280 \\
0.3048 & $\mathrm{ft}$ & $\mathrm{m}$ & 3.2808 \\
2.54 & inch $(\mathrm{es})$ & $\mathrm{cm}$ & 0.3937 \\
25.4 & inch $(\mathrm{es})$ & $\mathrm{mm}$ & 0.0394 \\
0.0749 & $\mathrm{oz} / 100 \mathrm{gal}$ & $\mathrm{g} \cdot \mathrm{L}^{-1}$ & 13.3526 \\
7.4892 & $\mathrm{oz} / \mathrm{gal}$ & $\mathrm{g} \cdot \mathrm{L}^{-1}$ & 0.1335 \\
1 & $\mathrm{ppm}$ & $\mu \mathrm{\mu g} \cdot \mathrm{mL}^{-1}$ & 1 \\
0.9464 & $\mathrm{qt}$ & $\mathrm{L}$ & 1.0567 \\
$\left({ }^{\circ} \mathrm{F}-32\right) \div 1.8$ & ${ }^{\circ} \mathrm{F}$ & ${ }^{\circ} \mathrm{C}$ & $\left({ }^{\circ} \mathrm{C} \times 1.8\right)+32$
\end{tabular}


2009a). Didecyl dimethyl ammonium chloride (KleenGrow ${ }^{\mathrm{TM}}$; Pace 49 , Burnaby, BC, Canada) is a disinfectant with algicide, bactericide, and fungicide activity that is supposed to increase efficacy of certain insecticides against western flower thrips (J. McWhorter, personal communication). However, there is no quantitative information to support claims that adding compounds such as disinfectants will enhance efficacy of pesticide mixtures. Nonetheless, greenhouse producers continually seek compounds that may increase the performance of insecticides or reduce the prospect of resistance (Georghiou, 1986). For example, greenhouse producers have been known to add sugar to insecticide spray solutions to supposedly enhance efficacy against western flower thrips (Parrella, 1995). However, Cloyd and Gillespie (2012) demonstrated that sugar-based compounds do not increase efficacy of insecticides against western flower thrips.

There is evidence indicating pesticide mixtures may increase the rate of resistance to both active ingredients, especially if insect and/or mite populations contain more than one resistance mechanism (Bielza, 2008; Stenersen, 2004). Despite this, greenhouse producers of horticultural crops including cut flowers or potted plants commonly apply various pesticides together including insecticides, miticides, and fungicides into a single spray solution (Cloyd, 2009a). However, producers may inadvertently apply pesticide mixtures that are less effective and potentially harmful to plants compared with applying pesticides separately (Cloyd, 2009a).

Producers may also mix together pesticides with similar modes of action, which could possibly lead to pest populations developing resistance to the individual pesticides in the mixture (Cloyd, 2009a) via cross or multiple resistance (Brattsten et al., 1986; Comins, 1986; Forgash, 1984; Mani, 1985; Stenersen, 2004). Although pesticide mixtures are commonly used against aphids, whiteflies (Aleyrodidae), spider mites, and thrips (Thripidae), very few documented reports are associated with efficacy of mixtures on western flower thrips infesting potted flowering plants and the impact of disinfectants on these mixtures (Cloyd, 2009a). Nonetheless, more information is needed on pesticide mixtures that are effective against one of the major insect pests of horticultural crops grown in greenhouses, western flower thrips (Kirk, 2002; Robb et al., 1995; Tommasini and Maini, 1995). Therefore, the objectives of this study were 2-fold: 1) identify binary pesticide mixtures that are effective in suppressing populations of western flower thrips under greenhouse conditions, and 2 ) assess the role of the disinfectant, didecyl dimethyl ammonium chloride, in the efficacy of pesticide mixtures. The results of this study will assist greenhouse producers in avoiding the use of ineffective pesticide mixtures when dealing with western flower thrips.

\section{Materials and methods}

Two experiments were conducted to evaluate selected binary pesticide mixtures and identify those that were efficacious against western flower thrips. Expt. 1 involved three trials using pesticides commonly applied by greenhouse producers, which could be applied as pesticide mixtures against western flower thrips (R.A. Cloyd, personal observation). Expt. 2 assessed the impact of the disinfectant, didecyl dimethyl ammonium chloride, on efficacy of pesticide mixtures against western flower thrips. The procedures used for both experiments in evaluating the efficacy of pesticide and pesticide mixtures against western flower thrips have been used in similar studies (Cloyd, 2013; Cloyd and Gillespie, 2012; Cloyd et al., 2009; Willmott et al., 2013).

A number of the pesticides used in this study are classified as selective. These include spinosad $\left(\right.$ Conserve ${ }^{\circledR}$; Dow AgroSciences, Indianapolis, IN), pyridalyl (Overture ${ }^{\circledR}$; Valent U.S.A., Walnut Creek, CA), bifenazate (Floramite $^{\circledR}$; OHP, Mainland, PA), and pymetrozine (Endeavor ${ }^{\mathrm{TM}}$; Syngenta, Greensboro, NC). Other pesticides used in the experiments may be classified as broad spectrum based on the number and variety of insect and/or mite target pests. These include abamectin $\left(\right.$ Avid $^{\circledR}$, Syngenta), fluvalinate (Mavrik Aquaflow ${ }^{\circledR}$; Wellmark International, Schaumburg, IL), azadirachtin (Azatin $\left.{ }^{\circledR} \mathrm{XL}, \mathrm{OHP}\right)$, chlorfenapyr (Pylon ${ }^{\circledR} ;$ BASF, Research Triangle Park, NC), tolfenpyrad (Hachi-Hachi ${ }^{\circledR}$; SePRO, Carmel, IN), spirotetramat (Kontos $\left.{ }^{\circledR}, \mathrm{OHP}\right)$, and petroleum oil (Pure-Spray $^{\top \mathrm{M}}$ Green; Petro-Canada
Lubricants, Mississauga, ON, Canada). All these insecticides are registered for use against thrips in the United States. We also included two fungicides, fenhexamid $\left(\right.$ Decree $^{\circledR}$; SePRO) and azoxystrobin (Heritage $^{\circledR}$; Syngenta) that are used against gray mold (Botrytis cinerea) and certain powdery mildews (Erysiphales), which are common diseases of transvaal daisy (Rogers and Tjia, 1990).

EXPT. 1: EFFECT OF BINARY PESTICIDE MIXTURES ON WESTERN FLOWER THRIPS. This experiment, which included three trials, was conducted in a glass-covered greenhouse. All procedures were similar in the three trials. Yellow cut transvaal daisy flowers were obtained from a wholesale broker (Koehler \& Dramm of Missouri, Kansas City, MO). No pesticides had been applied to the cut flowers before purchase from the broker, so the possibility of pesticide residues negatively affecting western flower thrips survival was minimal. Flowering transvaal daisy was used in this study as a model host plant based on its susceptibility to western flower thrips (Daughtrey et al., 1997) and potential phytotoxicity risks. Individual flowers can be isolated and remain a suitable host for development and reproduction of western flower thrips while avoiding cross-contamination among experimental units (Cloyd and Gillespie, 2012; Willmott et al., 2013). Flower stems were excised 2.0 to 3.0 inches below the base of the flowers and placed into $22-\mathrm{mm}$ low-background borosilicate glass vials containing tap water. One yellow transvaal daisy cut flower was placed into each glass vial. The glass vials were inserted into circular plastic containers $(250 \mathrm{~mL})$ with sand, which held the glass vial containing tap water and the cut flower upright during the trials. One container or cut flower was equal to one experimental unit.

The plastic containers, with the cut flowers, were positioned in a polyvinyl chloride (PVC) open pipe frame on a wire-mesh bench $(16 \times 5 \mathrm{ft})$, and the designated treatment containers, with the cut flowers, were spatially arranged in a completely randomized design. A 50\% black knit shadecloth (Hummert International, Earth City, $\mathrm{MO}$ ) was placed over the PVC frame to protect the cut flowers from direct sunlight, and preserve longevity and 
host suitability. Each cut flower was artificially infested with 20 adult western flower thrips (24- to 48 -h old) obtained from laboratory-reared colonies in the Department of Entomology at Kansas State University, Manhattan. The colonies were maintained on green bean (Phaseolus vulgaris) under $24 \pm 5{ }^{\circ} \mathrm{C}, 50 \%$ to $60 \%$ relative humidity $(\mathrm{RH})$, and $24 / 0 \mathrm{~h}$ (light/dark). These colonies, which have not been exposed to pesticides for at least 6 years, have been used in previous studies (Cloyd, 2013; Cloyd and Gillespie, 2012; Willmott et al., 2013).

To infest flowers, adults were aspirated into 9-dram plastic vials (BioQuip Products, Rancho Dominguez, CA), added to each flower, and allowed to establish for $2 \mathrm{~d}$ before application of the pesticide treatments. Flowers were sprayed using a 1.0 -qt plastic spray bottle (SprayPRO, Detroit, MI) 2-d postinfestation. Each flower was sprayed to runoff with $\approx 15 \mathrm{~mL}$ of spray solution. This spray volume thoroughly saturated the flower surface and allowed the spray solution to penetrate into the disk portion of the flowers where western flower thrips typically reside. The glass vials were refilled regularly with tap water to maintain quality of the cut flowers. The temperature inside the greenhouse during the three trials was $22 \pm 3{ }^{\circ} \mathrm{C}$ with $\mathrm{RH}$ between $50 \%$ and $60 \%$.

The experiment used different treatment combinations (mixtures) for each of the three semifield trials. There were five replications per treatment and treatment combination. The treatment combinations and the rates used for each semifield trial are presented in Table 1 . Seven days after application of the treatments, flowers were excised just below the sepals, placed into plastic petri dishes $(14 \mathrm{~cm}$ diameter) with lids, and then destructively sampled in the laboratory. The numbers of live, dead, and total number of adults and nymphs were counted to obtain population data for each replicate.

Percent western flower thrips mortality values for each trial were calculated by dividing the number of dead western flower thrips by the total number (live + dead) recovered per flower (replicate). Percent western flower thrips mortality values were normalized using an arcsin

Table 1. Pesticides and mixtures, and rates used in all three trials for Expt. 1 to evaluate the efficacy of binary pesticide mixtures against western flower thrips.

\begin{tabular}{|c|c|c|}
\hline Pesticides and mixtures $^{\mathrm{z}}$ & Labeled rate (per 100 gal) & Rates used (per \\
\hline \multicolumn{3}{|l|}{ Trial 1} \\
\hline Spinosad & $6.0 \mathrm{fl} \mathrm{oz}$ & $0.44 \mathrm{~mL}$ \\
\hline Pymetrozine & $4.0 \mathrm{oz}$ & $0.28 \mathrm{~g}$ \\
\hline Abamectin & $8.0 \mathrm{fl} \mathrm{oz}$ & $0.59 \mathrm{~mL}$ \\
\hline Pyridalyl & $8.0 \mathrm{oz}$ & $0.56 \mathrm{~g}$ \\
\hline Fluvalinate & $7.0 \mathrm{fl} \mathrm{oz}$ & $0.51 \mathrm{~mL}$ \\
\hline Chlorfenapyr & $2.6 \mathrm{fl} \mathrm{oz}$ & $0.19 \mathrm{~mL}$ \\
\hline \multirow[t]{2}{*}{ Spinosad + pymetrozine } & $6.0 \mathrm{fl} \mathrm{oz}$ & $0.44 \mathrm{~mL}$ \\
\hline & $4.0 \mathrm{oz}$ & $0.28 \mathrm{~g}$ \\
\hline \multirow[t]{2}{*}{ Spinosad + abamectin } & $6.0 \mathrm{fl} \mathrm{oz}$ & $0.44 \mathrm{~mL}$ \\
\hline & $8.0 \mathrm{fl} \mathrm{oz}$ & $0.59 \mathrm{~mL}$ \\
\hline \multirow[t]{2}{*}{ Pyridalyl + fluvalinate } & $8.0 \mathrm{oz}$ & $0.56 \mathrm{~g}$ \\
\hline & $7.0 \mathrm{fl} \mathrm{oz}$ & $0.51 \mathrm{~mL}$ \\
\hline \multicolumn{3}{|l|}{ Trial 2} \\
\hline Abamectin + bifenazate & $6.0 \mathrm{fl} \mathrm{oz}$ & $0.44 \mathrm{~mL}$ \\
\hline Abamectin & $8.0 \mathrm{fl} \mathrm{oz}$ & $0.59 \mathrm{~mL}$ \\
\hline Bifenazate & $8.0 \mathrm{fl} \mathrm{oz}$ & $0.59 \mathrm{~mL}$ \\
\hline Pyridalyl & $8.0 \mathrm{oz}$ & $0.56 \mathrm{~g}$ \\
\hline Azadirachtin & $16.0 \mathrm{fl} \mathrm{oz}$ & $1.18 \mathrm{~mL}$ \\
\hline Petroleum oil & $2.0 \mathrm{gal}$ & $18.9 \mathrm{~mL}$ \\
\hline \multirow[t]{2}{*}{ Abamectin + bifenazate } & $8.0 \mathrm{fl} \mathrm{oz}$ & $0.59 \mathrm{~mL}$ \\
\hline & $8.0 \mathrm{fl} \mathrm{oz}$ & $0.59 \mathrm{~mL}$ \\
\hline \multirow[t]{2}{*}{ Pyridalyl + azadirachtin } & $8.0 \mathrm{oz}$ & $0.56 \mathrm{~g}$ \\
\hline & $16.0 \mathrm{fl} \mathrm{oz}$ & $1.18 \mathrm{~mL}$ \\
\hline \multirow[t]{2}{*}{ Pyridalyl + petroleum oil } & $8.0 \mathrm{oz}$ & $0.56 \mathrm{~g}$ \\
\hline & $2.0 \mathrm{gal}$ & $18.9 \mathrm{~mL}$ \\
\hline \multicolumn{3}{|l|}{ Trial 3} \\
\hline Spinosad & $6.0 \mathrm{fl} \mathrm{oz}$ & $0.44 \mathrm{~mL}$ \\
\hline Pyridalyl & $8.0 \mathrm{oz}$ & $0.56 \mathrm{~g}$ \\
\hline Tolfenpyrad & $22.0 \mathrm{fl} \mathrm{oz}$ & $1.62 \mathrm{~mL}$ \\
\hline Fenhexamid & $1.0 \mathrm{lb}$ & $1.14 \mathrm{~g}$ \\
\hline Azoxystrobin & $4.0 \mathrm{oz}$ & $0.56 \mathrm{~g}$ \\
\hline \multirow[t]{2}{*}{ Spinosad + fenhexamid } & $6.0 \mathrm{fl} \mathrm{oz}$ & $0.44 \mathrm{~mL}$ \\
\hline & $1.0 \mathrm{lb}$ & $1.14 \mathrm{~g}$ \\
\hline \multirow[t]{2}{*}{ Spinosad + azoxystrobin } & $6.0 \mathrm{fl} \mathrm{oz}$ & $0.44 \mathrm{~mL}$ \\
\hline & $2.0 \mathrm{oz}$ & $0.05 \mathrm{~g}$ \\
\hline \multirow[t]{2}{*}{ Pyridalyl + fenhexamid } & $8.0 \mathrm{oz}$ & $0.56 \mathrm{~g}$ \\
\hline & $1.0 \mathrm{lb}$ & $1.14 \mathrm{~g}$ \\
\hline \multirow[t]{2}{*}{ Pyridalyl + azoxystrobin } & $8.0 \mathrm{oz}$ & $0.56 \mathrm{~g}$ \\
\hline & $4.0 \mathrm{oz}$ & $0.56 \mathrm{~g}$ \\
\hline
\end{tabular}

${ }^{7}$ Abamectin (Avid ${ }^{\circledast}$; Syngenta, Greensboro, NC), abamectin + bifenazate (Sirocco ${ }^{\mathrm{TM}}$; OHP, Mainland, PA), azadirachtin $\left(\right.$ Azatin $\left.^{\circledast} \mathrm{XL}, \mathrm{OHP}\right)$, azoxystrobin (Heritage ${ }^{\circledast}$, Syngenta), bifenazate (Floramite $\left.{ }^{\circledast}, \mathrm{OHP}\right)$, chlorfenapyr (Pylon ${ }^{\otimes}$; BASF, Research Triangle Park, NC), fenhexamid (Decree ${ }^{\otimes}$; SePRO, Carmel, IN), fluvalinate (Mavrik

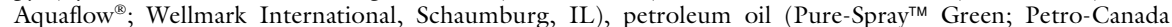
Lubricants, Mississauga, Ontario, Canada), pymetrozine (Endeavor ${ }^{\mathrm{TM}}$, Syngenta), pyridalyl (Overture ${ }^{\circledast}$; Valent U.S.A., Walnut Creek, CA), spinosad (Conserve ${ }^{\oplus}$; Dow AgroSciences, Indianapolis, IN), and tolfenpyrad (HachiHachi $^{\circledR}$, SePro).

${ }^{y} 1 \mathrm{fl} \mathrm{oz} / 100 \mathrm{gal}=0.0781 \mathrm{~mL} \cdot \mathrm{L}^{-1}, \mathrm{l} \mathrm{oz} / 100 \mathrm{gal}=0.0749 \mathrm{~g} \cdot \mathrm{L}^{-1}, \mathrm{l} \mathrm{mL} / \mathrm{qt}=1.0567 \mathrm{~mL} \cdot \mathrm{L}^{-1}=0.1353 \mathrm{fl} \mathrm{oz} / \mathrm{gal}, \mathrm{l}$ $\mathrm{g} / \mathrm{qt}=1.0567 \mathrm{~g} \cdot \mathrm{L}^{-1}=0.1411 \mathrm{oz} / \mathrm{gal}$.

square root transformation procedure (Little and Hills, 1978) and then subject to a one-way analysis of variance with treatment as the main effect (SAS version 9.1; SAS Institute, Cary, NC). Significant differences among treatment means were identified using a Fisher's protected least significant difference test at $P \leq 0.05$. All data presented are nontransformed.
EXPT. 2: EFFECT OF DIDECYL DIMETHYL AMMONIUM CHLORIDE ON THE EFFICACY OF BINARY PESTICIDE MIXTURES AGAINST WESTERN FLOWER THRIPS. Forty cut yellow transvaal daisy flowers were obtained from the same broker as in Expt. 1.

Two days after preparing the flowers (Expt. 1), 20 adult western flower thrips (24- to 48-h old) obtained 
Table 2. Pesticide, labeled rate, and rate used in Expt. 2 evaluating the efficacy of binary pesticide mixtures against western flower thrips.

\begin{tabular}{lcc}
\hline Pesticide $^{\mathbf{z}}$ & Labeled rate $($ per $\mathbf{~} \mathbf{0 0}$ gal) & $\begin{array}{c}\mathbf{y} \\
(\text { per } \mathbf{~ q t})^{\mathbf{y}}\end{array}$ \\
\hline $\begin{array}{l}\text { Tolfenpyrad } \\
\text { Didecyl dimethyl }\end{array} \quad 22 \mathrm{fl} \mathrm{oz}$ & $1.6 \mathrm{~mL}$ \\
$\quad$ ammonium chloride (DDAC) & $1.0 \mathrm{~mL}$ \\
Spirotetramat & $13 \mathrm{fl} \mathrm{oz}$ & $0.3 \mathrm{~mL}$ \\
Pyridalyl & $3.4 \mathrm{fl} \mathrm{oz}$ & $0.6 \mathrm{~g}$ \\
Tolfenpyrad + DDAC & $8 \mathrm{oz}$ & $1.6 \mathrm{~mL}+1.0 \mathrm{~mL}$ \\
Spirotetramat + DDAC & $22 \mathrm{fl} \mathrm{oz}+13 \mathrm{fl} \mathrm{oz}$ & $0.3 \mathrm{~mL}+1.0 \mathrm{~mL}$ \\
Pyridalyl + DDAC & $3.4 \mathrm{fl} \mathrm{oz}+13 \mathrm{fl} \mathrm{oz}$ & $0.6 \mathrm{~g}+1.0 \mathrm{~mL}$ \\
\hline
\end{tabular}

${ }^{2}$ Didecyl dimethyl ammonium chloride (KleenGrow ${ }^{\mathrm{TM}}$; Pace 49, Burnaby, BC, Canada), pyridalyl (Overture ${ }^{\circledR}$ Valent U.S.A., Walnut Creek, CA), spirotetramat (Kontos ${ }^{\circledR}$; OHP, Mainland, PA), and tolfenpyrad (HachiHachi $^{\circledast} ;$ SePro, Carmel, IN)

${ }^{\mathrm{y}} \mathrm{l} \mathrm{fl} \mathrm{oz} / 100 \mathrm{gal}=0.0781 \mathrm{~mL} \cdot \mathrm{L}^{-1}, \mathrm{l} \mathrm{oz} / 100 \mathrm{gal}=0.0749 \mathrm{~g} \cdot \mathrm{L}^{-1}, 1 \mathrm{~mL} / \mathrm{qt}=1.0567 \mathrm{~mL} \cdot \mathrm{L}^{-1}=0.1353 \mathrm{fl} \mathrm{oz} / \mathrm{gal}$ $1 \mathrm{~g} / \mathrm{qt}=1.0567 \mathrm{~g} \cdot \mathrm{L}^{-1}=0.1411 \mathrm{oz} / \mathrm{gal}$.

${ }^{x} \mathrm{DDAC}$ is not labeled for use against western flower thrips; therefore, the rate used was suggested by the company representative (J. McWhorter, personal communication).

from the laboratory-reared colonies were aspirated into 9-dram plastic vials, added to each flower, and allowed to establish for $2 \mathrm{~d}$ before application of the treatments. Pesticide treatments were mixed with tap water at the recommended labeled rates for western flower thrips (Table 2). Didecyl dimethyl ammonium chloride is not registered for use against western flower thrips, although anecdotal evidence suggests that it may have activity, so we used the suggested rate of $0.96 \mathrm{~mL} / \mathrm{qt}$ (J. McWhorter, personal communication). Pesticide mixtures were prepared at a $1: 1$ volume ratio. Applications of the pesticides and binary pesticide mixtures were made using a 1.0-qt plastic spray bottle. Each flower received $\approx 15 \mathrm{~mL}$ of the designated spray solution. After $5 \mathrm{~d}$, western flower thrips mortality, based on the number of live and dead western flower thrips recovered per flower was assessed using destructive sampling. Efficacy of each pesticide and binary pesticide mixture was based on percent mortality of western flower thrips. Data were determined and analyzed as described previously in Expt. 1 (see above).

\section{Results and discussion}

EXPT. 1: EFFECT OF BINARY PESTICIDE MIXTURES ON WESTERN FLOWER THRIPS. Treatment effect was significant in trial one $[F=$ 68.46; df (numerator, denominator) $=$ 9, 49; $P \leq 0.0001]$, trial two $(F=27.43 ; \mathrm{df}=9,49 ; P \leq 0.0001)$, and trial three $(F=68.37$; $\mathrm{df}=9,49$; $P \leq 0.0001)$. For trial one, all the spinosad and abamectin, and combination treatments resulted in $\geq 90 \%$ mortality of western flower thrips, whereas the other treatments resulted in $\leq 50 \%$ mortality (Fig. 1). The treatments and treatment combinations in trial two that resulted in $80 \%$ mortality against western flower thrips were the combination product containing the premixture of abamectin and bifenazate (Sirocco $\left.{ }^{\mathrm{TM}}, \mathrm{OHP}\right)$, abamectin, abamectin + bifenazate, pyridalyl, and pyridalyl + petroleum oil (Fig. 2). For trial three, both spinosad and pyridalyl, and all of the treatment combinations including the fungicides fenhexamid (Decree ${ }^{\circledR}$, SePRO) and azoxystrobin (Heritage ${ }^{\circledR}$, Syngenta) resulted in $80 \%$ mortality of western flower thrips (Fig. 3). Overall, all the binary pesticide mixtures evaluated (based on percent mortality) suppressed populations of western flower thrips in the yellow transvaal daisy flowers relative to the untreated or water control. In addition, none of the pesticides or binary pesticide mixtures was phytotoxic to the yellow transvaal daisy flowers.

EXPT. 2: EFFECT OF DIDECYL DIMETHYL AMMONIUM CHLORIDE ON THE EFFICACY OF BINARY PESTICIDE MIXTURES AGAINST WESTERN FLOWER THRIPS. There were significant differences among the treatments $(F=$ 22.04; df $=7,39 ; P \leq 0.0001)$ with pyridalyl the only pesticide that resulted in $80 \%$ mortality of western flower thrips (Fig. 4). In addition, the binary pesticide mixture of pyridalyl + didecyl dimethyl ammonium chloride provided significantly higher western flower thrips mortality (92\%) compared with pyridalyl alone (81\%). Pesticides and pesticide mixtures associated with tolfenpyrad, tolfenpyrad + didecyl dimethyl ammonium chloride, spirotetramat, and spirotetramat + didecyl dimethyl ammonium chloride resulted in $50 \%$ western flower thrips mortality (Fig. 4). Furthermore, there were no significant increases or decreases in western flower thrips mortality when tolfenpyrad or spirotetramat was mixed with didecyl dimethyl ammonium chloride. None of the pesticides or binary pesticide mixtures was phytotoxic to the yellow transvaal daisy flowers.

Results of this study indicate that many of the pesticide mixtures tested may be used by greenhouse producers without compromising suppression of western flower thrips. However, field populations that have been exposed to intensive selection pressure may be less susceptible to these binary pesticide mixtures. In laboratory bioassays, Willmott et al. (2013) determined that the labeled rate of spinosad $\left(56.2 \mu \mathrm{g} \cdot \mathrm{mL}^{-1}\right)$ is substantially higher than the $\mathrm{LC}_{50}\left(0.4 \mu \mathrm{g} \cdot \mathrm{mL}^{-1}\right)$ of susceptible baseline populations of western flower thrips. Regardless, this study provides important information for greenhouse producers that will help them avoid using those binary pesticide mixtures that failed to suppress our baseline population of western flower thrips.

The results obtained in this study were similar to Cloyd (2013) and Willmott et al. (2013) in which 90\% mortality was obtained with mixtures containing spinosad and abamectin. Results were also similar for pyridalyl + petroleum oil when used at the labeled rate. There was lower efficacy $(\leq 80 \%$ mortality) for binary pesticide mixtures associated with pyridalyl + azadirachtin, pyridalyl + fenhexamid, and pyridalyl + azoxystrobin. The last two pesticides mixed with pyridalyl are fungicides, which are oftentimes used in pesticide mixtures along with insecticides (Cloyd, 2009a; Norgaard and Cedergreen, 2010). In this study, all the binary pesticide mixtures containing spinosad were effective in suppressing western flower thrips populations, which was similar to Willmott et al. (2013).

Previous research suggests pesticide mixtures of abamectin + azadirachtin (Warnock and Cloyd, 2005; Willmott et al., 2013) and pyridalyl + azadirachtin at the labeled rates (Cloyd, 2013) may exhibit reduced efficacy against western flower thrips 


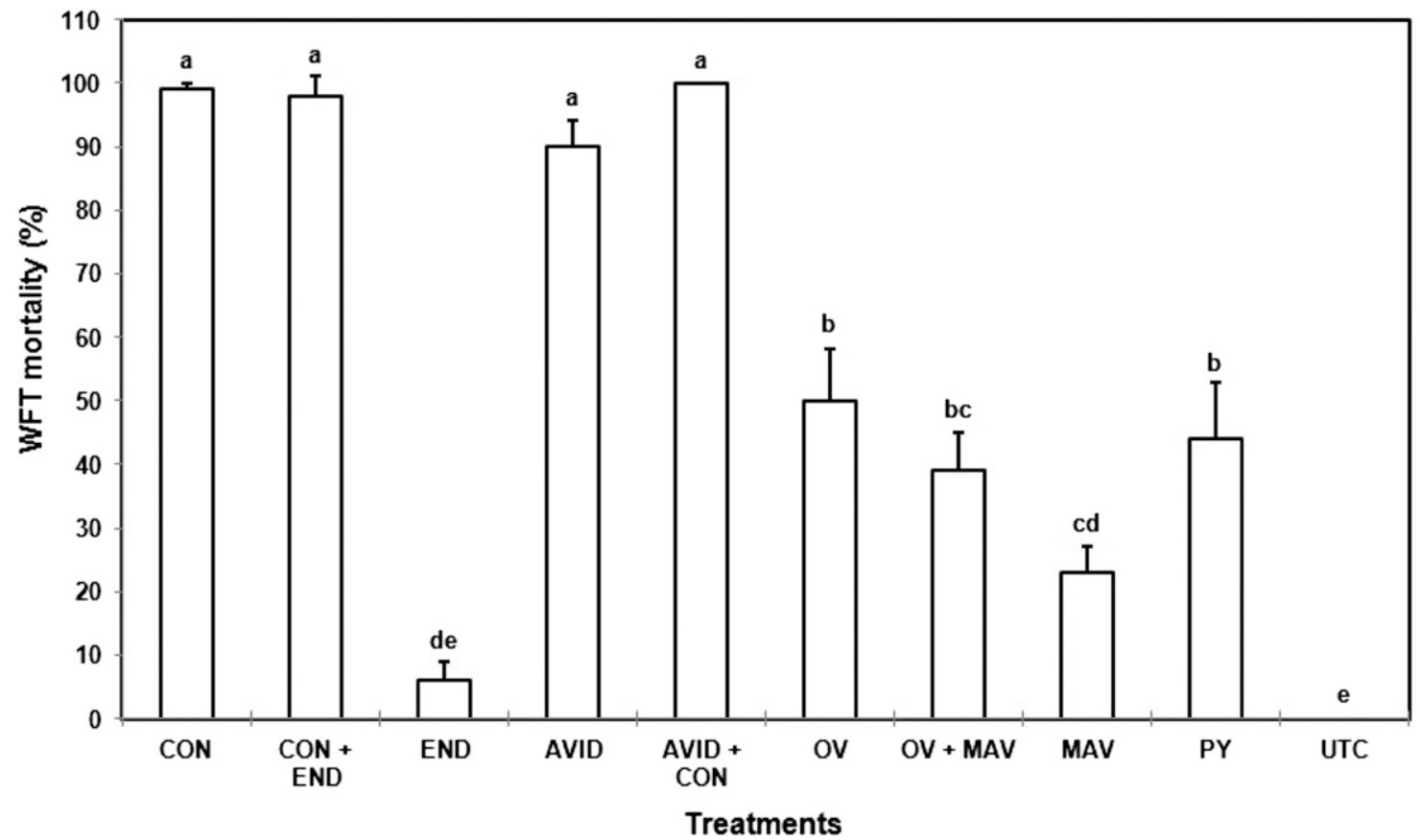

Fig. 1. Western flower thrips (WFT) mortality for all treatments associated with trial one in Expt. 1: CON = spinosad (Conserve $^{\circledR}$; Dow AgroSciences, Indianapolis, IN), CON + END = spinosad (Conserve ${ }^{\circledR}$, Dow AgroSciences) + pymetrozine

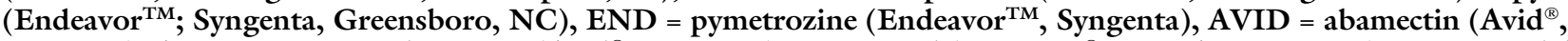
Syngenta), AVID + CON = abamectin $\left(\right.$ Avid ${ }^{\circledR}$, Syngenta $)+\operatorname{spinosad}^{(\text {Conserve }}{ }^{\circledR}$, Dow AgroSciences $)$, OV $=$ pyridalyl (Overture $^{\circledR}$; Valent U.S.A., Walnut Creek, CA), OV + MAV = pyridalyl (Overture ${ }^{\circledR}$, Valent U.S.A.) + fluvalinate (Mavrik Aquaflow $^{\circledR}$; Wellmark International, Schaumburg, IL), MAV = fluvalinate (Mavrik Aquaflow ${ }^{\circledR}$, Wellmark International), PY = chlorfenapyr $\left(\right.$ Pylon $^{\circledR}$; BASF, Research Triangle Park, NC), UTC = untreated control. Columns with the same lower case letter are not significantly different $(P \geq 0.05)$ as determined by Fisher's protected least significance difference mean separation test. Vertical bars represent the SE.

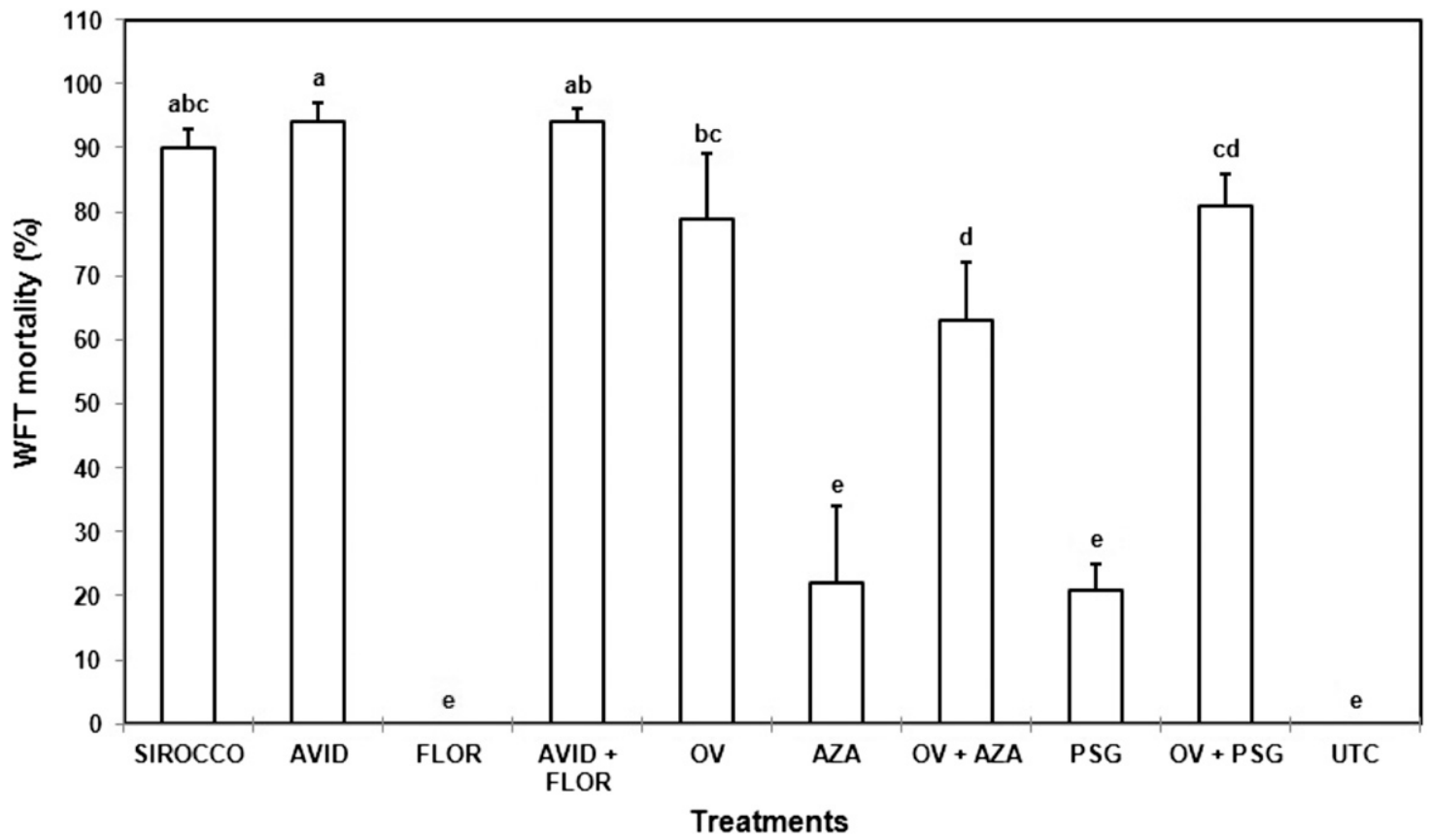

Fig. 2. Western flower thrips (WFT) mortality for all treatments associated with trial two in Expt. $1:$ SIROCCO = abamectin +

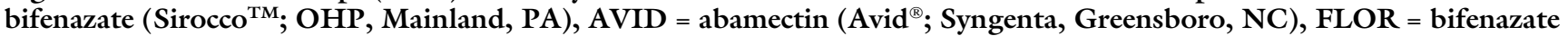
$\left(\right.$ Floramite $^{\circledR}$, OHP), AVID + FLOR = abamectin $\left(\right.$ Avid ${ }^{\circledR}$, Syngenta $)+$ bifenazate $\left(\right.$ Floramite $^{\circledR}$, OHP $)$, OV $=$ pyridalyl (Overture $^{\circledR}$; Valent U.S.A., Walnut Creek, CA), AZA = azadirachtin (Azatin ${ }^{\circledR}$ XL, OHP), OV + AZA = pyridalyl (Overture ${ }^{\circledR}$, Valent U.S.A.) + azadirachtin (Azatin ${ }^{\circledR}$ XL, OHP), PSG = petroleum oil (Pure-Spray ${ }^{\mathrm{TM}}$ Green; Petro-Canada Lubricants, Mississauga, ON, Canada), OV + PSG = pyridalyl (Overture ${ }^{\circledR}$, Valent U.S.A.) + petroleum oil (Pure-Spray ${ }^{\mathrm{TM}}$ Green, PetroCanada Lubricants), UTC = untreated control. Columns with the same lower case letter are not significantly different $(P \geq 0.05)$ as determined by Fisher's protected least significance difference mean separation test. Vertical bars represent the sE. 


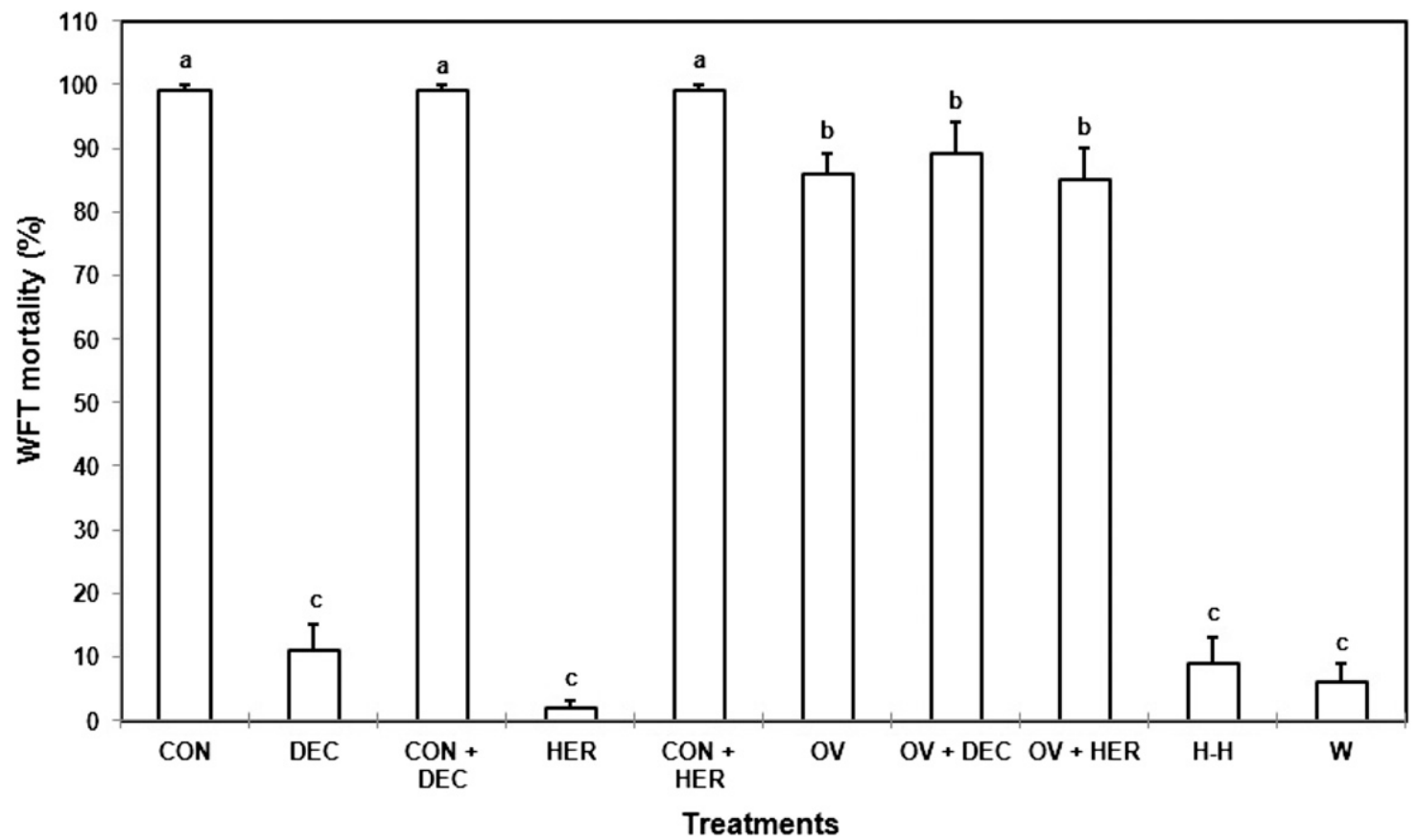

Fig. 3. Western flower thrips (WFT) mortality for all treatments associated with trial three in Expt. 1: CON = spinosad $\left(\right.$ Conserve $^{\circledR}$; Dow AgroSciences, Indianapolis, IN), DEC = fenhexamid $\left(\right.$ Decree $^{\circledR} ;$ SePRO, Carmel, IN), CON + DEC =

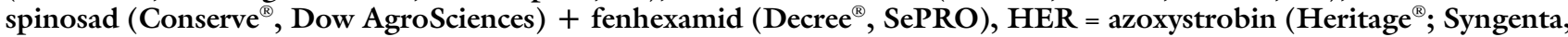
Greensboro, NC), CON + HER = spinosad $\left(\right.$ Conserve ${ }^{\circledR}$, Dow AgroSciences $)+$ azoxystrobin $\left(\right.$ Heritage ${ }^{\circledR}$, Syngenta $)$, OV $=$ pyridalyl (Overture ${ }^{\circledR}$; Valent U.S.A., Walnut Creek, CA), OV + DEC = pyridalyl (Overture ${ }^{\circledR}$, Valent U.S.A.) + fenhexamid $\left(\right.$ Decree $^{\circledR}$, SePRO), OV + HER = pyridalyl $\left(\right.$ Overture $^{\circledR}$, Valent U.S.A. $)+$ azoxystrobin $\left(\right.$ Heritage $^{\circledR}$, Syngenta $), \mathrm{H}-\mathrm{H}=$ tofenpyrad (Hachi-Hachi ${ }^{\circledR}$, SePRO), W = water control. Columns with the same lower case letter are not significantly different $(P \geq 0.05)$ as determined by Fisher's protected least significance difference mean separation test. Vertical bars represent the sE.

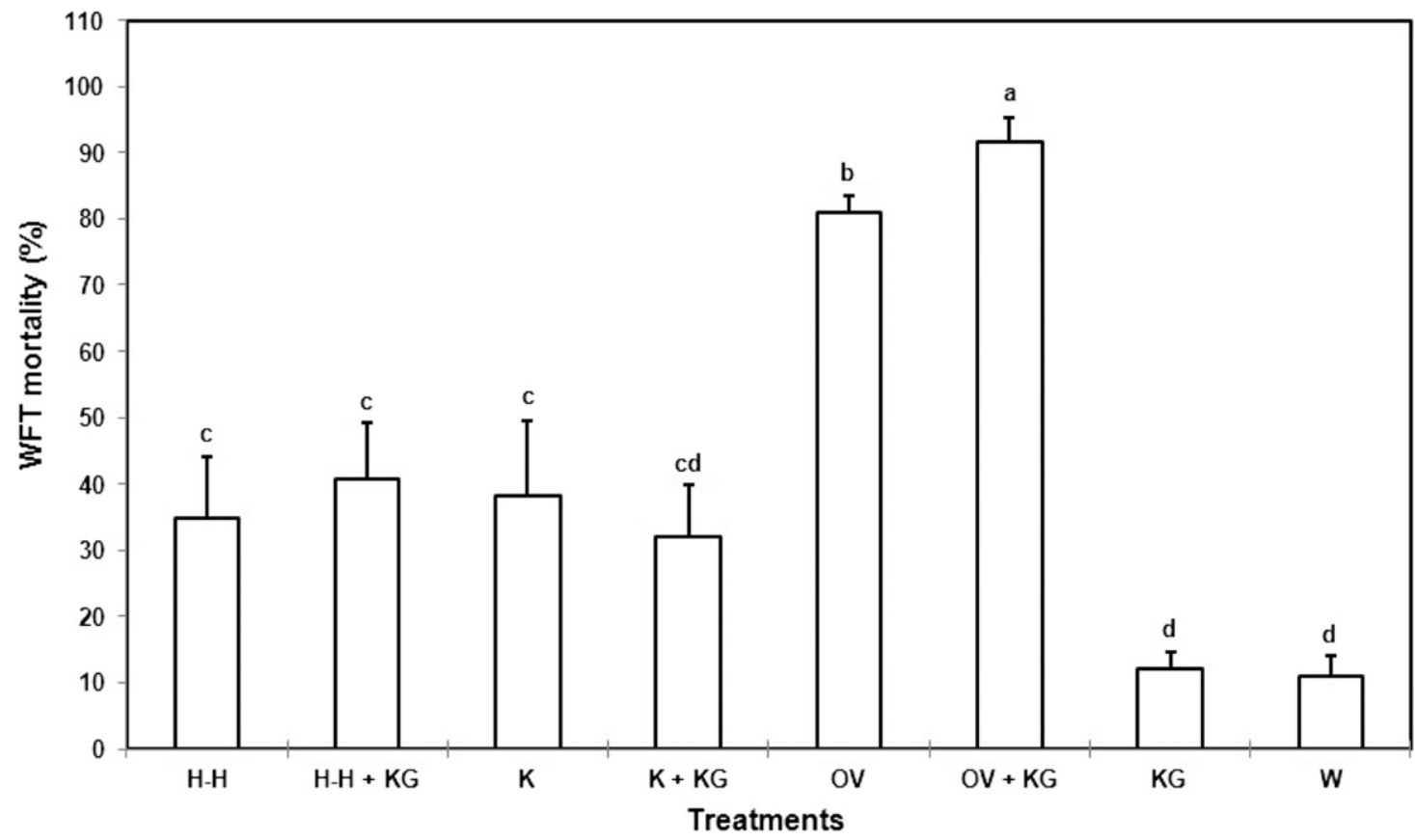

Fig. 4. Western flower thrips (WFT) mortality associated with Expt. 2: H-H = tolfenpyrad (Hachi-Hachi ${ }^{\circledR}$; SePRO, Carmel, IN),

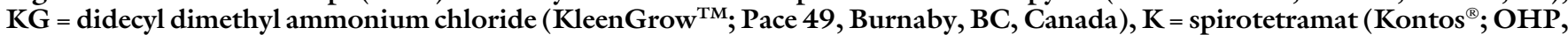
Mainland, PA), and OV = pyridalyl (Overture ${ }^{\circledR}$; Valent U.S.A., Walnut Creek, CA) and W = water control. Columns with the same lower case letter are not significantly different $(P \geq 0.05)$ as determined by Fisher's protected least significance difference mean separation test. Vertical bars represent the $S E$. 
populations compared with abamectin or pyridalyl applied separately. However, those binary pesticide mixtures that included azadirachtin resulted in reduced efficacy. Therefore, further research is needed to determine if the repellent and/or antifeedant activity of azadirachtin (Mordue et al., 1998; Schmutterer, 1990) is responsible for decreased efficacy (based on mortality) when azadirachtin is included in pesticide mixtures (Willmott et al., 2013).

In our study, the addition of didecyl dimethyl ammonium chloride did not enhance efficacy of the individual compounds against western flower thrips with the exception of the pyridalyl and didecyl dimethyl ammonium chloride mixture, which provided significantly higher mortality $(90 \%)$ of western flower thrips than pyridalyl alone (Fig. 4). Further studies are warranted to investigate the possible reasons (e.g., synergy) for this difference. Although tolfenpyrad and spirotetramat are labeled for use against the active life stages (nymphs and adults) of western flower thrips, in Expt. 2, both the individual treatments and mixtures with didecyl dimethyl ammonium chloride resulted in $<50 \%$ mortality (Fig. 4). Separate efficacy trials have demonstrated that tolfenpyrad is not effective against western flower thrips (R.A. Cloyd, unpublished data).

This study expands our understanding of the efficacy of pesticide mixtures, which will assist greenhouse producers in selecting appropriate combinations of pesticide mixtures. However, it is important to note that there are factors such as cross or multiple resistance that may increase the risk of resistance to pesticide mixtures used against western flower thrips (Bielza, 2008; Stenersen, 2004). This study was conducted using a susceptible baseline population of western flower thrips with no previous exposure to pesticides. Therefore, future research needs to be conducted to determine efficacy of binary pesticide mixtures on field populations of western flower thrips that in all likelihood have been exposed to most of the pesticides evaluated in this study. Nonetheless, with the continual introduction of selective pesticides that are labeled for only a few insect and/or mite pests' greenhouse producers are going to mix pesticides to reduce application costs. As such, it is essential to collate information to determine which pesticide mixtures may be effective in suppressing populations of western flower thrips, and other insect and/or mite pests. This study elaborates on our comprehensive evaluation, based on previous studies (Cloyd et al., 2007; Warnock and Cloyd, 2005), in determining those pesticide mixtures that should be avoided against western flower thrips. Furthermore, it is important that greenhouse producers implement an integrated pest management strategy, not only against western flower thrips but also against other insect and/or mite pests that may involve using pesticide mixtures in conjunction with scouting, cultural control, sanitation, and physical and biological control (Bielza, 2008; Cloyd, 2009b; Hoy, 1998).

\section{Literature cited}

Bielza, P. 2008. Insecticide resistance management strategies against the western flower thrips, Frankliniella occidentalis. Pest Mgt. Sci. 64:1131-1138.

Brattsten, L.B., C.W. Holyoke, J.R. Leeper, and K.F. Raffa. 1986. Insecticide resistance: Challenges to pest management and basic research. Science 231:1255-1260.

Cabello, T. and R. Canero. 1994. Pesticide mixtures used on garden crops in greenhouses in southeast Spain: Cost analysis. Boletin Sanidad Vegetal Plagus 20:429-436.

Cloyd, R.A. 2009a. Getting mixed-up: Are greenhouse producers adopting appropriate pesticide mixtures to manage arthropod pests? HortTechnology 19:638-646.

Cloyd, R.A. 2009b. Western flower thrips (Frankliniella occidentalis) management on ornamental crops grown in greenhouses: Have we reached an impasse? Pers. Technol. 3:1-9.

Cloyd, R.A. 2011. Pesticide mixtures, p. 69-80. In: M. Stoytcheva (ed.). Pesticide formulations, effects, fate. InTech, Rijeka, Croatia.

Cloyd, R.A. 2012. Insect and mite management in greenhouses, p. 391-441. In: P.V. Nelson (ed.). Greenhouse operation and management. 7th ed. Pearson Prentice Hall, Upper Saddle River, NJ.

Cloyd, R.A. 2013. Effect of pesticide mixtures on the western flower thrips (Frankliniella occidentalis) associated with cut flowers. Cut Flower Qrtly. 25:24-25.

Cloyd, R.A., C.L. Galle, and S.R. Keith. 2007. Greenhouse pesticide mixtures for control of silverleaf whitefly (Homoptera: Aleyrodidae) and twospotted spider mite (Acari: Tetranychidae). J. Entomol. Sci. 42:375-382.

Cloyd, R.A., C.L. Galle, S.R. Keith, N.A. Kalscheur, and K.E. Kemp. 2009. Effect of commercially available plant-derived essential oil products on arthropod pests. J. Econ. Entomol. 102:1567-1579.

Cloyd, R.A. and J.D. Gillespie. 2012. Effect of sugar-based compounds in enhancing the efficacy of insecticides against the western flower thrips. HortTechnology 22:177-184.

Comins, H.N. 1986. Tactics for resistance management using multiple pesticides. Agr. Economic Environ. 16:129-148.

Daughtrey, M.L., R.K. Jones, J.W. Moyer, M.E. Daub, and J.R. Baker. 1997. Tospoviruses strike the greenhouse industry. Plant Dis. 81:1220-1230.

Forgash, A.J. 1984. History, evolution, and consequences of insecticide resistance. Pestic. Biochem. Physiol. 22:178-186.

Georghiou, G.P. 1986. The magnitude of the resistance problem, p. 14-43. In: Pesticide resistance: Strategies and tactics for management. Natl. Acad. Sci., Washington, DC.

Gerin, C., T.H. Hance, and G. Van Impe. 1994. Demographical parameters of Frankliniella occidentalis (Pergande) (Thysanoptera: Thripidae). J. Appl. Entomol. 118:370-377.

Hoy, M.A. 1998. Myths: Models and mitigation of resistance to pesticides. Philosophical Trans. Royal Soc. London Biol. Sci. 353:1787-1795.

Immaraju, J.A., T.D. Paine, J.A. Bethke, K.L. Robb, and J.P. Newman. 1992. Western flower thrips (Thysanoptera: Thripidae) resistance to insecticides in coastal California greenhouses. J. Econ. Entomol. 85:9-14.

Jensen, S.E. 2000. Insecticide resistance in the western flower thrips, Frankliniella occidentalis. Integrated Pest Mgt. Rev. 5:131-146.

Kirk, W.D.J. 2002. The pest and vector from the west: Frankliniella occidentalis, p. 31-44. In: R. Marullo and L.A. Mound (eds.). Thrips and tospoviruses: Proc. 7th Intl. Symp. Thysanoptera. Austral. Natl. Insect Collection, Canberra, Australia.

Lewis, T. 1997. Pest thrips in perspective, p. 1-14. In: T. Lewis (ed.). Thrips as crop pests. CAB Intl., Wallingford, UK. 
Little, T.M. and F.J. Hills. 1978. Agricultural experimentation: Design and analysis. Wiley, New York, NY.

Loughner, R.L., D.F. Warnock, and R.A. Cloyd. 2005. Resistance of greenhouse, laboratory, and native populations of western flower thrips to spinosad. HortScience 40:146-149.

Mani, G.S. 1985. Evolution of resistance in the presence of two insecticides. Genetics 109:761-783.

Mordue, A.J., M.S.J. Simmonds, S.V. Ley, W.M. Blaney, W. Mordue, M. Nasiruddin, and A.J. Nisbet. 1998. Actions of azadirachtin, a plant allelochemical against insects. Pestic. Sci. 54:277-284.

Mound, L.A. 1996. The thysanoptera vector species of tospoviruses. Acta Hort. 431:298-309.

Norgaard, K.B. and N. Cedergreen. 2010. Pesticide cocktails can interact synergistically on aquatic organisms. Environ. Sci. Pollution Res. 17:957-967.

O'Connor-Marer, P.J. 2000. Pesticides, p. 65-108. In: P.J. O'Connor-Marer (ed.). The safe and effective use of pesticides. Univ. California Agr. Natural Resources Commun. Serv., Oakland, CA.

Parrella, M.P. 1995. IPM: Approaches and prospects, p. 357-363. In: B.L. Parker, M. Skinner, and T. Lewis (eds.).
Thrips biology and management. Plenum Press, New York, NY.

Robb, K.L., J. Newman, J.K. Virzi, and M.P. Parrella. 1995. Insecticide resistance in western flower thrips, p. 341-346. In: B.L. Parker, M. Skinner, and T. Lewis (eds.). Thrips biology and management. Plenum, New York, NY.

Rogers, M.N. and B.O. Tjia. 1990. Gerbera production for cut flowers and pot plants. Timber Press, Portland, OR.

Roush, R.T. 1993. Occurrence, genetics, and management of insecticide resistance. Parasitol. Today 9:174-179.

Schmutterer, H. 1990. Properties and potential of natural pesticides from the neem tree, Azadirachta indica. Annu. Rev. Entomol. 35:271-297.

Stenersen, J. 2004. Chemical pesticides: Mode of action and toxicology. CRC Press, Boca Raton, FL.

Tabashnik, B.E. 1989. Managing resistance with multiple pesticide tactics: Theory, evidence, and recommendations. J. Econ. Entomol. 82:1263-1269.

Thompson, H. and S. Wilkins. 2003. Assessment of the synergy and repellency of pyrethroid/fungicide mixtures. Bull. Insectology 56:131-134.
Tommasini, M.G. and S. Maini. 1995. Frankliniella occidentalis and other thrips harmful to vegetable and ornamental crops in Europe, p. 1-42. In: A.J.M. Loomans, J.C. Van Lenteren, S. Tommasini, S. Maini, and J. Riudavets (eds.). Biological control of thrips pests. Wageningen Agr. Univ. Papers, Wageningen, The Netherlands.

Ullman, D.E., T.L. German, J.L. Sherwood, D.M. Westcot, and F.A. Cantone. 1993. Tospovirus replication in insect vector cells: Immunocytochemical evidence that the non-structural protein encoded by the $S$ RNA of tomato spotted wilt tospovirus is present in thrips vector cells. Phytopathology 83:456-463.

Wang, W. and L. Taashiu. 1994. Toxicity of mixtures of several miticides with the fungicide triforine against the two-spotted mite on Roses. Bul. Taichung Distrib. Agr. Improve. Sta. 44:1-11.

Warnock, D.F. and R.A. Cloyd. 2005. Effects of pesticide mixtures in controlling western flower thrips (Thysanoptera: Thripidae). J. Entomol. Sci. 40:54-66.

Willmott, A.L., R.A. Cloyd, and K.Y. Zhu. 2013. Efficacy of pesticide mixtures against the western flower thrips (Thysanoptera: Thripidae) under laboratory and greenhouse conditions. J. Econ. Entomol. 106:247-256. 